\title{
Effects of supplemental phytase and phosphorus on histological, mechanical and chemical traits of tibia and performance of turkeys fed on soyabean-meal-based semi-purified diets high in phytate phosphorus
}

\author{
BY H. QIAN ${ }^{1}$, E. T. KORNEGAY ${ }^{*}$ AND H. P. VEIT ${ }^{2}$ \\ ${ }^{1}$ Department of Animal and Poultry Sciences and ${ }^{2}$ Department of Biomedical Sciences and \\ Pathobiology, Virginia Polytechnic Institute and State University, Blacksburg, \\ VA 24061-0306, USA
}

(Received 10 May 1995 - Revised 25 September 1995 - Accepted 9 November 1995)

\begin{abstract}
Tibial traits were investigated for turkey poults fed on soyabean-meal-based semi-purified diets high in phytate $P(2.2 \mathrm{~g} / \mathrm{kg})$ with added phytase and inorganic $P$. Dietary treatments were: (1) $2.7 \mathrm{~g}$ non-phytate $\mathrm{P}(\mathrm{nP}) / \mathrm{kg}$; (2) diet $1+1000 \mathrm{U}$ phytase/kg diet; (3) $3.6 \mathrm{~g} \mathrm{nP} / \mathrm{kg}$; (4) diet $3+800 \mathrm{U}$ phytase; (5) $4.5 \mathrm{~g}$ $\mathrm{nP} / \mathrm{kg}$; (6) diet $5+600 \mathrm{U}$ phytase; (7) $6.0 \mathrm{~g} \mathrm{nP} / \mathrm{kg}$. Added phytase and $\mathrm{nP}$ increased $(P<0.006)$ tibial dry matter, ash weight and content, body-weight gain, feed intake and gain:feed. The $\mathrm{Mg}$ and $\mathrm{Zn}$ concentrations in the tibial ash were also increased $(P<0.001$ and $P<0-09$ respectively) by added phytase or nP; tibial $P$ and $\mathrm{Ca}$ concentrations tended to be increased. Hypertrophy zone width of the tibial proximal end decreased $(P<0.001)$, while proliferating zone width, tibial length, and widths at the long and short axes increased $(P<0.003)$ as phytase and $\mathrm{n} P$ were added. The addition of phytase also tended to enlarge the cartilaginous zone width, which was linearly increased $(P<0.05)$ by added $n P$. Disorganization scores of the hypertrophy zone and trabecular bone were low, approaching normal $(P<0.05)$, for turkey poults fed on diets with phytase supplementation, and tibial abnormality scores were linearly decreased $(P<0-001)$ as $\mathrm{nP}$ levels increased (zero score is considered normal). Adding phytase and $n P$ improved the orderliness of development, mineralization and arrangement of cartilage and bone cells, and alleviated the effects of $P$ deficiency on the histological and gross structure of the tibias. Tibial shear stress increased $(P<0.04)$ as phytase and $\mathrm{nP}$ were added. In summary, similar improvements in bone characteristics were achieved for turkey poults fed on a P-deficient diet supplemented with either phytase or $\mathrm{nP}$.
\end{abstract}

Phytase: Phosphorus: Bone: Histology

Compared with normally fed animals, P-deficient animals grow slowly, have depressed appetite and low efficiency of feed utilization (Underwood, 1981). More than $60 \% \mathrm{P}$ in soyabean meal is in the form of phytate, which has low $\mathrm{P}$ availability and leads to a $\mathrm{P}$ deficiency for poultry (Reddy et al. 1982; National Research Council, 1994). Impairment of bone growth and histological development are the most obvious signs of a $\mathbf{P}$ deficiency, the latter of which is characterized by irregular cartilage development with irregular bone cell growth and arrangement (Yoshida, 1986; Edwards \& Veltamann, 1988). At the same time, bones in P-deficient animals are shorter and have reduced bone mass and mineral content.

Phytase supplementation of poultry diets has great potential for improving phytate-P utilization, and has led to a marked improvement in poultry performance and bone mineralization (Simons et al. 1990; Qian et al. 1994; Ravindran et al. 1995). However, only

* For reprints. 
limited studies have examined the influence of added phytase and inorganic $P$ on tibial traits of poults. Several criteria have been used to evaluate the effectiveness of phytase in increasing $P$ availability in turkey diets. Many researchers have preferred to use growth rate and bone ash content because of their simplicity (Sullivan \& Douglas, 1990). There are no reports about the effect of phytase supplementation on the histological bone development of turkey poults. Therefore, the objective of the present study was to investigate the histological, mechanical and chemical traits of the tibia in poults given phytase and inorganic $\mathrm{P}$ in soyabean-meal-based semi-purified diets high in phytate $\mathrm{P}$.

\section{MATERIALS AND METHODS}

British United turkey poults ( $1 \mathrm{~d}$ old) were used to investigate the effects of phytase (Natuphos ${ }^{\circledast}$, BASF Corp., Mount Olive, NJ, USA) supplementation of semi-purified diets on bone characteristics and performance of turkey poults. Poults $(n 280)$ were assigned to the following seven dietary treatments (four pens of ten poults/treatment) to represent potentially maximum differences: (1) $2.7 \mathrm{~g}$ non-phytate $\mathrm{P}(\mathrm{nP}) / \mathrm{kg}$; (2) diet $1+1000 \mathrm{U}$ phytase $/ \mathrm{kg}$ diet; (3) $3.6 \mathrm{~g} \mathrm{nP} / \mathrm{kg}$; (4) diet $3+800 \mathrm{U}$ phytase; (5) $4.5 \mathrm{~g} \mathrm{nP} / \mathrm{kg}$; (6) diet $5+600 \mathrm{U}$ phytase; (7) $6.0 \mathrm{~g} \mathrm{nP} / \mathrm{kg}$. The diets were designed to provide increasing levels of inorganic $P$ with decreasing phytase levels. A phytase unit $(\mathrm{U})$ is defined as the quantity of enzyme that liberates $1 \mu \mathrm{mol}$ inorganic $\mathrm{P}$ per min from $1.5 \mathrm{~mm}$ sodium phytate at $\mathrm{pH} 5.5$ and $37^{\circ}$ (Engelen et al. 1994).

Semi-purified diets containing soyabean meal (dehulled, solvent-extracted, $485 \mathrm{~g}$ crude protein $/ \mathrm{kg}$ ) as the only organic $\mathrm{P}$ source $(1-1 \mathrm{~g} \mathrm{nP} / \mathrm{kg})$ were used as basal diets (Table 1$)$. Maize starch, glucose and rapeseed oil were used instead of maize as energy sources. This basal diet was low in $\mathbf{P}$ availability for turkey poults. The desired levels of $\mathrm{nP}$ in the basal diets were achieved by adding varying levels of defluorinated phosphate. Treatments with the lower level of $\mathrm{nP}$ without phytase supplementation, however, were expected to result in some signs of tibial histological abnormalities. The $\mathrm{Ca}$ : total $\mathrm{P}$ ratio was maintained at $2: 1$ in all diets by adding limestone, except in diet 7 where the ratio was $1 \cdot 46: 1$. Defluorinated phosphate and limestone were added to the diets at the expense of maize starch. Since the phytate was supplied only from the soyabean meal, the dietary phytate P content $(2 \cdot 2 \mathrm{~g} / \mathrm{kg})$ was similar in all diets. On the day of hatch, poults were wingbanded and randomly assigned to pens in electrically heated, raised wire-floored battery brooders in an environmentally controlled room. Poults were exposed to continuous fluorescent light. The diets were fed in a mash form from 1 to $21 \mathrm{~d}$ of age. Feed and water were available ad libitum. The care and treatment of poults followed published guidelines (Consortium, 1988).

Body weights and feed intake were recorded on a pen basis at weekly intervals. On day 21 , five poults from each treatment were randomly selected and killed. Left tibias were removed and frozen for further mechanical and chemical analysis. The tibias were later thawed and stripped of all soft tissues. Tibial morphology (abnormality) scores were recorded ( 0 , normal; 1 , abnormal shape and size; 2 , seriously abnormal shape and size) (Edwards \& Veltamann, 1988). Then, after recording the length and width of each tibia, a $50 \mathrm{~mm}$ section of bone was cut from the centre shank of the tibia. Wall thickness of each end of this section of bone was measured at two sites (widest and narrowest) using calipers. An Instron Universal Testing Machine (Model 1123, Instron Corp., Canton, MA 02021, USA) was used for shear force determination at a loading rate of $2 \mathrm{~mm} / \mathrm{min}$, and the bone shear stress was calculated as outlined by Combs et al. (1991). After the test of shear force and stress, tibial samples were oven-dried at $105^{\circ}$ for $24 \mathrm{~h}$ and ashed in a muffle furnace at $600^{\circ}$ for $6 \mathrm{~h}$. Tibial ash was expressed as a proportion of dry matter. Afterwards, the ash was wet-digested using $16 \mathrm{mM}-\mathrm{HNO}_{3}-12 \mathrm{M}_{-} \mathrm{HClO}_{4}(5: 3 \mathrm{v} / \mathrm{v})$. The $\mathrm{Ca}, \mathrm{Mg}$ and $\mathrm{Zn}$ contents 
Table 1. Ingredients and calculated composition of basal diets $(\mathrm{g} / \mathrm{kg})$

\begin{tabular}{|c|c|c|c|c|}
\hline \multirow[b]{2}{*}{ Items } & \multicolumn{4}{|c|}{ Non-phytate phosphorus $(\mathrm{g} / \mathrm{kg})$} \\
\hline & $2 \cdot 7$ & $3-6$ & $4 \cdot 5$ & $6 \cdot 0$ \\
\hline \multicolumn{5}{|l|}{ Ingredients $(\mathrm{g} / \mathrm{kg})$} \\
\hline Soyabean meal $(485 \mathrm{~g} \mathrm{CP} / \mathrm{kg})$ & $577 \cdot 5$ & 577.5 & 577.5 & 577.5 \\
\hline Maize starch* & $194 \cdot 9$ & $189 \cdot 3$ & 183.7 & $186 \cdot 3$ \\
\hline Glucose $\dagger$ & $100 \cdot 0$ & $100 \cdot 0$ & $100 \cdot 0$ & $100-0$ \\
\hline Rapeseed oil & 60.0 & 60.0 & 60.0 & 60.0 \\
\hline Celluloseł & $30-0$ & $30 \cdot 0$ & $30 \cdot 0$ & 300 \\
\hline Limestone & $15 \cdot 7$ & $16 \cdot 0$ & $16 \cdot 3$ & 4.9 \\
\hline Defluorinated phosphate & 7.8 & $13 \cdot 1$ & $18 \cdot 4$ & $27 \cdot 2$ \\
\hline Vitamin premix $\S$ & $6 \cdot 0$ & $6 \cdot 0$ & $6 \cdot 0$ & $6 \cdot 0$ \\
\hline Trace mineral premix & $2 \cdot 0$ & $2 \cdot 0$ & $2 \cdot 0$ & $2 \cdot 0$ \\
\hline Salt & $4 \cdot 0$ & $4 \cdot 0$ & $4 \cdot 0$ & $4 \cdot 0$ \\
\hline DL-Methionine & $2 \cdot 1$ & $2 \cdot 1$ & $2 \cdot 1$ & $2 \cdot 1$ \\
\hline \multicolumn{5}{|l|}{ Calculated composition $(\mathrm{g} / \mathrm{kg})$} \\
\hline $\mathrm{CP}$ & $280 \cdot 0$ & $280 \cdot 0$ & $280 \cdot 0$ & $280 \cdot 0$ \\
\hline Lysine & $18 \cdot 3$ & $18 \cdot 3$ & $18 \cdot 3$ & $18 \cdot 3$ \\
\hline Methionine plus cystine & $10 \cdot 5$ & $10 \cdot 5$ & 10.5 & $10 \cdot 5$ \\
\hline Calcium & $9 \cdot 8$ & 11.6 & $13 \cdot 4$ & $12 \cdot 0$ \\
\hline Total P & 4.9 & 5.8 & 6.7 & $8 \cdot 2$ \\
\hline Available $\mathrm{P}$ & $2 \cdot 7$ & 3.6 & $4 \cdot 5$ & $6 \cdot 0$ \\
\hline
\end{tabular}

$\mathrm{CP}$, crude protein.

* Food grade, National Starch and Chemical Co., Bridgewater, NJ 08807, USA

$†$ Clintose ${ }^{9}$, ADM Corn Processing, Clinton, IA 52732, USA.

¥ Purified cellulose, Grade BH200, International Filler Corp., NY 14120, USA.

$\S$ Supplied (/kg diet): retinyl acetate $2724 \mu \mathrm{g}$, cholecalciferol $199 \mu \mathrm{g}$, DL- $\alpha$-tocopheryl acetate $79 \mathrm{mg}$, menadione sodium bisulphite complex $2.2 \mathrm{mg}$, riboflavin $22 \mathrm{mg}$, calcium pantothenate $29 \mathrm{mg}$, niacin $99 \mathrm{mg}$, cyanocobalamin $0.033 \mathrm{mg}$, choline chloride $3036 \mathrm{mg}$, biotin $0.92 \mathrm{mg}$, pteroylmonoglutamic acid $9.2 \mathrm{mg}$, thiamin- $\mathrm{HCl} 22 \mathrm{mg}$, pyridoxine- $\mathrm{HCl} 9.2 \mathrm{mg}$, ethoxyquin $150 \mathrm{mg}$, virginiamycin $8.7 \mathrm{mg}$.

\|| Supplied (/kg diet): Mn $88 \mathrm{mg}, \mathrm{Zn} 95 \mathrm{mg}, \mathrm{Fe} 100 \mathrm{mg}$, Cu $12.5 \mathrm{mg}, \mathrm{I} 4 \mathrm{mg}$, Se $0.6 \mathrm{mg}$.

of tibia ash were determined with an atomic absorption spectrophotometer (Perkin Elmer, Model 5100 PC, Norwalk, Connecticut, USA). P content in tibial ash was determined photometrically (Association of Official Analytical Chemists, 1990).

Right tibias were also obtained, stripped of soft tissues at the time of slaughter, and split longitudinally using a small band saw (236 teeth $/ \mathrm{m}$ blade). The split halves of bones were fixed in $100 \mathrm{ml} / 1$ phosphorus-buffered formalin solution. Slices $(5 \mathrm{~mm}$ thick) of the proximal end of the split tibia were decalcified with formic acid solution $(500 \mathrm{ml} / \mathrm{l})$, embedded in paraffin, and cut into thin sections. Randomly selected sections were stained with haematoxylin and eosin and examined microscopically in a blind fashion (without knowledge of treatments). The widths of cartilaginous zones, proliferating zones, hypertrophic zones and trabecular bone density were evaluated and measured as units of the visual field. The orderliness of development, arrangement and calcification of the cartilage cells in cartilaginous, proliferative, and hypertrophy zones and bone cells in the trabecular bone of the tibial specimens were scored according to a 'disorganization score' $(0$, normal; 1 , slight disorganization; 2 , moderate disorganization; 3, severe disorganization) based on the degree of reduced amounts of trabecular bones and disorderliness of trabecular orientation. A zero score represented normal histologic morphology.

Data were analysed by the general linear model procedure of the Statistical Analysis 
Table 2. Effect of phytase and non-phytate phosphorus levels on performance and mechanical measurements of tibia of turkey poults*

(Mean values for five birds per treatment)

\begin{tabular}{|c|c|c|c|c|c|c|c|c|}
\hline $\begin{array}{l}\text { Treatment ... } \\
\text { Non-phytate } P(g / k g) \ldots \\
\text { Phytase }(U / \mathrm{kg}) \ldots\end{array}$ & $\begin{array}{l}1 \\
2 \cdot 7 \\
0\end{array}$ & $\begin{array}{c}2 \\
2 \cdot 7 \\
1000\end{array}$ & $\begin{array}{l}3 \\
3 \cdot 6 \\
0\end{array}$ & $\begin{array}{c}4 \\
3 \cdot 6 \\
800\end{array}$ & $\begin{array}{l}5 \\
4 \cdot 5 \\
0\end{array}$ & $\begin{array}{c}6 \\
4 \cdot 5 \\
600\end{array}$ & $\begin{array}{l}7 \\
6 \cdot 0 \\
0\end{array}$ & SEM \\
\hline \multicolumn{9}{|l|}{ Performance } \\
\hline Wt gain $(\mathrm{g}) \ddagger \S$ & 263 & 462 & 444 & 474 & 465 & 483 & 492 & $11 \cdot 6$ \\
\hline Feed intake $(\mathrm{g}) \dagger \ddagger$ & 572 & 659 & 648 & 700 & 683 & 667 & 720 & $19 \cdot 2$ \\
\hline Gain: feed $(\mathrm{g} / \mathrm{kg}) \S$ & 460 & 701 & 685 & 677 & 681 & 724 & 683 & $20 \cdot 0$ \\
\hline \multicolumn{9}{|l|}{ Mechanical measurements of tibia } \\
\hline Length $(\mathrm{mm})+t$ & $69 \cdot 4$ & $75 \cdot 0$ & $73 \cdot 5$ & $76 \cdot 3$ & $77 \cdot 2$ & $74 \cdot 5$ & $77 \cdot 2$ & $1 \cdot 2$ \\
\hline Width at long axis (mm)t & $4 \cdot 41$ & $4 \cdot 77$ & $4 \cdot 62$ & $4 \cdot 94$ & $5 \cdot 04$ & $5 \cdot 04$ & $5 \cdot 16$ & $0-12$ \\
\hline Width at short axis $(\mathrm{mm})+t$ & 3.47 & 3.99 & $3 \cdot 78$ & 4.09 & $4 \cdot 19$ & $4 \cdot 21$ & $4 \cdot 26$ & 0.13 \\
\hline Shear force $(\mathrm{N})$ & $85 \cdot 6$ & $89 \cdot 1$ & $93 \cdot 3$ & $113 \cdot 5$ & $99 \cdot 4$ & $110 \cdot 6$ & 101.8 & $9 \cdot 74$ \\
\hline Shear stress $(\mathrm{kg} / \mathrm{mm}) \dagger \ddagger$ & 1.05 & $2 \cdot 16$ & $2 \cdot 14$ & $2 \cdot 53$ & $2 \cdot 24$ & $2 \cdot 27$ & $1 \cdot 87$ & $0 \cdot 30$ \\
\hline
\end{tabular}

\footnotetext{
N, Newtons.

* For details of diets and procedures, see Table 1 and pp. 264 266.

$\dagger$ Phytase effect (comparison of treatments 1,3 and 5 v. 2, 4 and $6, P<0.05$ ).

$\ddagger$ P linear effect (comparison of treatments $1,3,5$ and $7, P<0.005$ ).

$\S$ Phytase effect (comparison of treatments 1,3 and 5 v. 2, 4 and $6, P<0.005$ ).
}

System (SAS, 1992) with pen means as the experimental unit for evaluating the poult performances and individual birds as the experimental unit for the other criteria. Comparisons between treatments with and without phytase supplementation were made using non-orthogonal contrasts to indicate the effects of supplemental phytase. Linear and quadratic effects of inorganic $\mathbf{P}$ addition were tested within treatments without phytase supplementation using orthogonal polynomials.

\section{RESULTS}

Body-weight gain and feed intake were linearly increased $(P<0.005)$ as the $\mathrm{nP}$ content of the diet increased, and increased $(P<0.05)$ when phytase was added to each of these $\mathrm{nP}$ diets (Table 2). Supplementation with phytase and inorganic phosphates also improved $(P<0.05)$ gain:feed ratios. Turkey poults fed on diets containing 3.6 or $4.5 \mathrm{~g} \mathrm{nP} / \mathrm{kg}$ supplemented with 800 or $600 \mathrm{U} / \mathrm{kg}$ diet respectively, reached maximum performance when compared with the control group $(6 \cdot 0 \mathrm{~g} \mathrm{nP} / \mathrm{kg})$.

The length, widths at long and short axes, and shear stress of tibias were linearly increased $(P<0.005)$ as the $\mathrm{nP}$ content of the diet was increased from 2.7 to $4.5 \mathrm{~g} \mathrm{nP} / \mathrm{kg}$, but did not increase further when the $\mathrm{nP}$ content was increased to $6.0 \mathrm{~g} / \mathrm{kg}$ (Table 2). Phytase added to each of these nP diets further increased $(P<0.05)$ all of these measurements. Shear force of tibias tended to increase as diets were supplemented with phytase and/or inorganic $P$.

Supplementation with inorganic $P$ linearly increased $(P<0.001) D M$, ash weight and proportion of ash in the tibia, improved tibial mineralization by linearly enhancing tibial mineral contents of $\mathrm{Mg}$ and $\mathrm{Zn}(P<0.05)$, and tended to increase tibial $\mathrm{Ca}$ and $\mathrm{P}$ contents (Table 3). The addition of phytase to each $\mathrm{nP}$ basal diet further increased $(P<0.05)$ these measurements. By comparison with the control group $(6.0 \mathrm{~g} \mathrm{nP} / \mathrm{kg})$, diets containing 3.6 or $4.5 \mathrm{~g} \mathrm{nP} / \mathrm{kg}$ supplemented with 800 or $600 \mathrm{U}$ phytase $/ \mathrm{kg}$ diet respectively, seemed to supply adequate $\mathrm{P}$ for bone mineralization in poults. 
Table 3. Effect of supplemental phytase and non-phytate phosphorus levels on mineral contents in tibia ash of turkey poults*

(Mean values for five birds per treatment group)

\begin{tabular}{|c|c|c|c|c|c|c|c|c|}
\hline $\begin{array}{l}\text { Treatment ... } \\
\text { Non-phytate P }(\mathrm{g} / \mathrm{kg}) \ldots \\
\text { Phytase }(\mathrm{U} / \mathrm{kg}) \ldots\end{array}$ & $\begin{array}{l}1 \\
2 \cdot 7 \\
0\end{array}$ & $\begin{array}{l}2 \\
2 \cdot 7 \\
1000\end{array}$ & $\begin{array}{l}3 \\
3 \cdot 6 \\
0\end{array}$ & $\begin{array}{l}4 \\
3 \cdot 6 \\
800\end{array}$ & $\begin{array}{l}5 \\
4 \cdot 5 \\
0\end{array}$ & $\begin{array}{l}6 \\
4 \cdot 5 \\
600\end{array}$ & $\begin{array}{l}7 \\
6 \cdot 0 \\
0\end{array}$ & SEM \\
\hline DM $(\mathrm{g}) \dagger+$ & $1 \cdot 15$ & 1.56 & $1 \cdot 42$ & $1 \cdot 65$ & $1 \cdot 74$ & 1.69 & 1.77 & 0.08 \\
\hline Ash wt $(\mathrm{g}) \dagger^{+}$ & $0 \cdot 32$ & 0.56 & 0.48 & 0.63 & 0.64 & 0.68 & 0.70 & 0.04 \\
\hline Ash (g/kg bone) $\dagger$ & 274 & 356 & 341 & 387 & 368 & 404 & 395 & $7 \cdot 3$ \\
\hline $\mathrm{Ca}(\mathrm{g} / \mathrm{kg}$ ash $) \ddagger$ & 310 & 345 & 313 & 371 & 330 & 363 & 354 & $17 \cdot 3$ \\
\hline $\mathrm{P}(\mathrm{g} / \mathrm{kg}$ ash $)$ & 172 & 180 & 179 & 183 & 177 & 177 & 180 & 3.5 \\
\hline $\mathrm{Mg}(\mathrm{g} / \mathrm{kg}$ ash $) \dagger \|$ & 5.9 & $6 \cdot 6$ & $6 \cdot 6$ & $7 \cdot 4$ & $7 \cdot 0$ & $8 \cdot 3$ & $8 \cdot 3$ & 0.2 \\
\hline $\mathrm{Zn}(\mathrm{g} / \mathrm{kg}$ ash $)$ & $0 \cdot 22$ & $0 \cdot 28$ & $0 \cdot 31$ & 0.31 & 0.32 & 0.33 & 0.40 & 0.04 \\
\hline
\end{tabular}

* For details of diets and procedures, see Table 1 and pp. 264266.

$\dagger$ Phytase effect (comparison of treatments 1,3 and 5 v. 2, 4 and $6, P<0.005$ ).

$\ddagger$ P linear effect (comparison of treatments $1,3,5$ and $7, P<0.001$ ).

$\S$ Phytase effect (comparison of treatments 1,3 and 5 v. 2,4 and $6, P<0.05$ ).

\|I $P$ linear effect (comparison of treatments $1,3,5$ and $7, P<0.05$ ).

Table 4. Effects of supplemental phytase and non-phytate phosphorus levels on histological traits of tibia of turkey poults*

(Mean values for five birds per treatment group)

\begin{tabular}{|c|c|c|c|c|c|c|c|c|}
\hline $\begin{array}{l}\text { Treatment ... } \\
\text { Non-phytate } \mathrm{P}(\mathrm{g} / \mathrm{kg}) \ldots \\
\text { Phytase }(\mathrm{U} / \mathrm{kg}) \ldots\end{array}$ & $\begin{array}{l}1 \\
2 \cdot 7 \\
0\end{array}$ & $\begin{array}{c}2 \\
2 \cdot 7 \\
1000\end{array}$ & $\begin{array}{l}3 \\
3 \cdot 6 \\
0\end{array}$ & $\begin{array}{l}4 \\
3 \cdot 6 \\
800\end{array}$ & $\begin{array}{l}5 \\
4 \cdot 5 \\
0\end{array}$ & $\begin{array}{c}6 \\
4 \cdot 5 \\
600\end{array}$ & $\begin{array}{l}7 \\
6 \cdot 0 \\
0\end{array}$ & SEM \\
\hline \multicolumn{9}{|l|}{ Width of proximal tibial zones $\dagger$} \\
\hline Cartilaginous zone $(40 \times) \S$ & $0 \cdot 44$ & $0 \cdot 58$ & 0.57 & 0.63 & 0.58 & $0 \cdot 66$ & 0.59 & 0.06 \\
\hline Proliferative zone $(100 \times) \$$ & 0.50 & 0.65 & 0.67 & 0.68 & 0.68 & $0 \cdot 69$ & 0.70 & 0.03 \\
\hline Hypertrophic zone $(100 \times) \| ף$ & $1 \cdot 65$ & $0 \cdot 86$ & $1 \cdot 01$ & 0.71 & 0.81 & 0.68 & 0.76 & 0.07 \\
\hline Trabecular bone density $(100 \times)$ & $0 \cdot 18$ & 0.20 & $0 \cdot 22$ & 0.22 & 0.22 & 0.25 & $0 \cdot 26$ & 0.03 \\
\hline \multicolumn{9}{|l|}{$\begin{array}{l}\text { Disorganization score of proximal tibia } \\
\text { zones** }\end{array}$} \\
\hline Cartilaginous zone & $1 \cdot 0$ & $1 \cdot 0$ & $1 \cdot 4$ & 0.4 & $1 \cdot 4$ & $1 \cdot 2$ & $1 \cdot 0$ & $0 \cdot 3$ \\
\hline Proliferative zone & $1 \cdot 2$ & $1 \cdot 0$ & $1 \cdot 0$ & 0.6 & $1 \cdot 0$ & 0.8 & 0.6 & $0 \cdot 3$ \\
\hline Hypertrophic zone & $2 \cdot 0$ & 1.0 & 1.8 & 0.8 & 1.8 & $1 \cdot 2$ & $1 \cdot 2$ & $0 \cdot 3$ \\
\hline Trabecular bone & $1 \cdot 2$ & $0 \cdot 2$ & $1 \cdot 4$ & 0.2 & $1 \cdot 0$ & 0.6 & 0.4 & $0 \cdot 4$ \\
\hline Tibial abnormality scores** & $1 \cdot 6$ & 0.6 & 0.2 & 0.4 & 0 & 0 & 0 & 0.27 \\
\hline
\end{tabular}

* For details of diets and procedures, see Table 1 and pp. 264-266.

$\uparrow$ Recorded as units of the visual field. Number in parentheses indicates magnification level.

\$ Phytase effect (comparison of treatments 1,3 , and 5 v. 2, 4 and $6, P<0.05$ ).

$\S P$ linear effect (comparison of treatments $1,3,5$ and $7, P<0.05$ ).

$\|$ Phytase effect (comparison of treatments 1,3 , and 5 v. 2,4 and $6, P<0.005$ ).

T $P$ linear effect (comparison of treatments $1,3,5$ and $7, P<0.001$ ).

** Based on $0=$ normal, $1=$ abnormal and $2=$ seriously abnormal.

Irregularity of the differentiation of the chondroblasts and chondrocytes and particularly a widened hypertrophy zone were noted in the tibias of birds fed on diets with low $\mathrm{nP}$ and without supplementary phytase. Width of the cartilaginous and proliferative zones increased linearly $(P<0.05)$ as the $n P$ content of the diet increased (Table 4 ; Fig. 1(b)). 
(a)

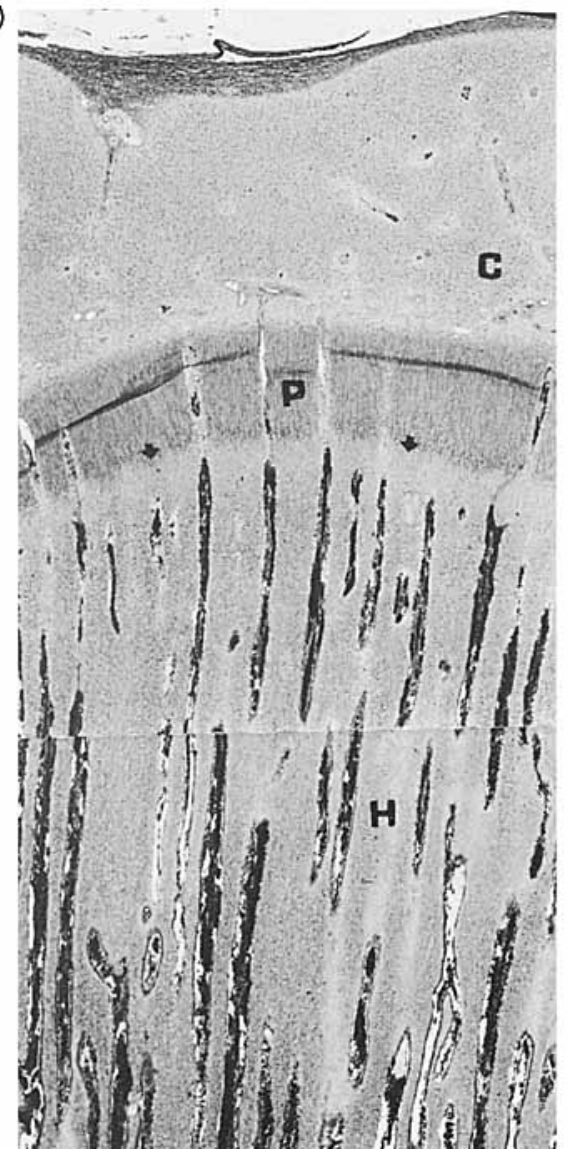

(b)

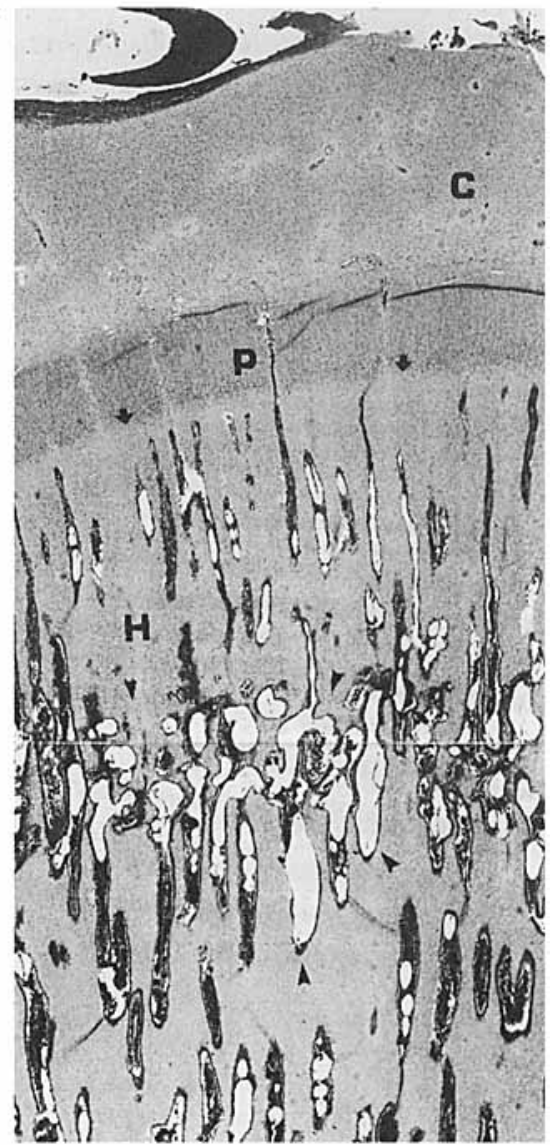

Fig. 1. (a) Normal proximal tibial section from a 21 -d-old male turkey poult fed on a diet supplemented with phytase (600 U/kg diet) and non-phytate $P(n P)(4.5 \mathrm{~g} / \mathrm{kg})$ showing the cartilaginous zone (C), proliferative zone (P) and hypertrophy zone $(\mathrm{H})$. Note the orderliness of orientation of the trabeculas (seen as dark, long streaks) and the sharp demarcation between $\mathrm{P}$ and $\mathrm{H}$ zones (black arrows) due to orderly cell differentiation. The $\mathrm{H}$ zone is narrow and interfaces regularly with the trabecular bone (haematoxylin and eosin stain, $\times 125$ ). (b) Abnormal proximal tibial section from a 21 -d-old male turkey poult fed on a diet without phytase or non-phytate $P$ $(2.7 \mathrm{~g} / \mathrm{kg})$. There is slight loss of sharp demarcation between the proliferative zone $(\mathrm{P})$ and hypertrophy zone $(\mathrm{H})$ (demarcation denoted by black arrows). The hypertrophy zone, in which cartilage columns are increased in length, is widened, and interfaces with the irregular vasculature and trabeculas (black points) (haematoxylin and eosin stain, $\times 125$ ).

Proliferative zones also widened $(P<0.05)$ as phytase was added to each of the $\mathrm{nP}$ diets, while width of the hypertrophy zone decreased linearly $(P<0.001)$ as the $\mathrm{nP}$ content of the diets increased, and decreased further $(P<0.005)$ as phytase was added to each of the $\mathrm{nP}$ diets. Trabecular bone density tended to increase as the nP contents of diets increased and as phytase was added to each of the nP diets (Fig. 2(a)). Orderliness (a lower disorganization score) for each zone was generally favoured by higher $\mathrm{nP}$ levels and added phytase, particularly for the hypertrophy zone and trabecular bone development (Table 4, $P<0.05$ ). Also, higher levels of $\mathrm{nP}$ and supplemental phytase resulted in lower tibial abnormality scores (Table $4, P<0.003$ ).

Abnormality of chondrocyte differentiation or irregular differentiation of cartilage cells in the proliferative and hypertrophy zones which were associated with the $\mathrm{P}$ deficiency are 
(a)

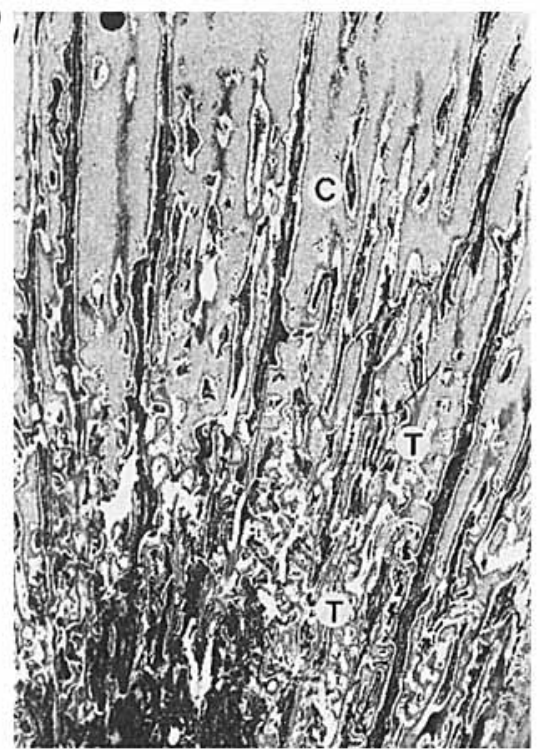

(b)

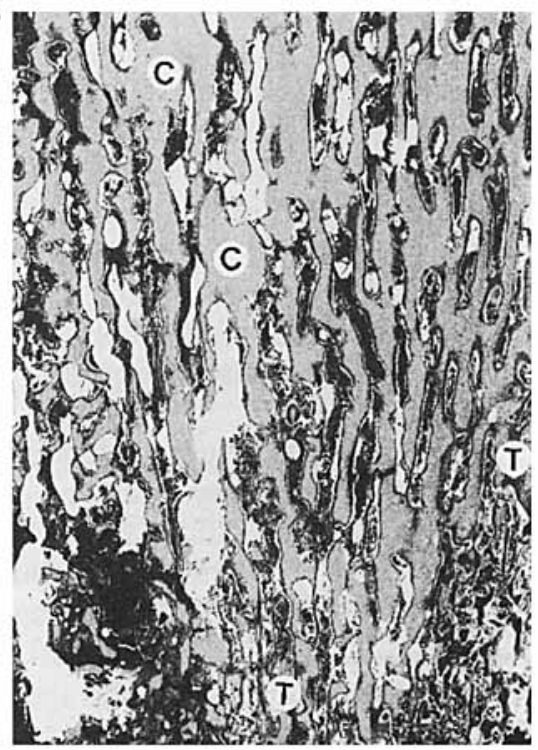

Fig. 2. (a) Normal trabecular bone in a 21-d-old male turkey poult fed on a diet supplemented with phytase $(600 \mathrm{U} / \mathrm{kg}$ diet $)$ and non-phytate $\mathrm{P}(4.5 \mathrm{~g} / \mathrm{kg})$. Note the orderly cartilage $(\mathrm{C})$ and dense trabecular bone (T) orientation to each other (haematoxylin and eosin stain, $\times 200$ ). (b) Abnormal trabecula in a 21-d-old male turkey poult fed on a diet with no phytase and non-phytate $P$ addition $(2.7 \mathrm{~g} / \mathrm{kg})$. Note the disorganized hypertrophy zone cartilage $(\mathrm{C})$, variably reduced amounts of trabecular bone $(\mathrm{T})$ and disorderliness of trabecular orientation (haematoxylin and eosin stain, $\times 200$ ).

shown in Fig. 1(b). Cartilage columns that showed less resorption and bone replacement in the hypertrophy zone were lengthened, and variably tapered. The trabeculas of the tibia of birds fed without inorganic $P$ and phytase supplementation were observed to have variably reduced amounts of, and more disorganized, trabecular bone (Fig. 2(b)). Osteoblasts and osteoclasts of these trabeculas appeared smaller and less numerous. Birds fed on diets with phytase or inorganic $\mathrm{P}$ addition tended to have more normal bone organization (Figs. 1(a), 2(a)). In terms of histological traits, no differences were found between poults given $3.6 \mathrm{~g} \mathrm{nP} / \mathrm{kg}$ diet supplemented with $800 \mathrm{U}$ phytase $/ \mathrm{kg}$ or $4.5 \mathrm{~g} \mathrm{nP} / \mathrm{kg}$ diet with $600 \mathrm{U}$ phytase $/ \mathrm{kg}$ and control group turkey poults given $6.0 \mathrm{~g} \mathrm{nP} / \mathrm{kg}$ diet.

\section{DISCUSSION}

Phytate in soyabean meal reduces not only the availability of $P$ but also that of other minerals such as $\mathrm{Ca}, \mathrm{Mg}$ and $\mathrm{Zn}$ because of the formation of insoluble complexes, which result in the poor mineralization of bones (Lacey \& Huffer, 1982; Walker et al. 1992; Qian et al. 1994). The present study demonstrates that microbial phytase supplementation can increase tibial DM, ash weight and proportion, and ash mineral content, which suggests that phytase improves bioavailability of phytate $\mathrm{P}$ and other minerals in the diet. It is clear that supplemental phytase releases $\mathrm{P}$ as well as $\mathrm{Ca}, \mathrm{Mg}$ and $\mathrm{Zn}$ bound to intact phytate (Wise, 1983; Simons et al. 1990; Qian et al. 1994). Phytase hydrolysis of phytate was presumed to have allowed for better bone mineralization. Our chemical analysis data also show that the addition of inorganic $\mathbf{P}$ to $\mathbf{P}$-deficient diets tended to increase the tibial $\mathrm{Ca}$ and $\mathrm{P}$ content and significantly increased $\mathrm{Zn}$ and $\mathrm{Mg}$ proportions in the tibial ash. This could be attributed to the increased $P$ availability resulting in an increase in absorption of trace minerals by increasing feed intake. 
The histological features of the normal proximal end of tibia in turkey poults have been illustrated in Figs. 1(a), 2(a), in which there are three zones: the cartilaginous zone, the proliferative zone and the hypertrophy zone. The cartilage zone, or cartilaginous epiphysis, is on the top. The proliferative zone, the growth plate, is composed of flattened chondrocytes arranged in columns. They become enlarged and separated by increased matrix as the cells gradually mature. The hypertrophy zone consists mainly of enlarged chondrocytes surrounded by basophilic extracellular matrix and bordered by invading metaphyseal vessels, and developing osseous trabeculas. Long et al. (1984) described these cartilaginous zones in more detail, in which they further divided the hypertrophy zone into three sections: a narrow hypertrophied zone, a degenerating hypertrophied zone and a metaphyseal spongiosa.

In the present study the enlarged hypertrophy zone, a sign of P deficiency, was the typical finding in the tibias of turkey poults given low $\mathrm{nP}$ and no phytase supplement (Figs. 1(b), 2(b)), which is consistent with results of Yoshida (1986) and Edwards \& Veltamann (1988) in their chick studies. This was also supported by the observation of Long et al. (1984) who observed lengthening of the degenerating hypertrophied zone and metaphyseal spongiosa in birds with $\mathbf{P}$ deficiencies. They suggested that the histological hallmark in the P-deficient avian species was widening of the metaphyseal spongiosa and to a lesser extent the narrowing of the growth plate proliferative zone. These changes suggested defective cartilaginous development and faulty osseous development. The widened hypertrophy zone was attributed to the delay in differentiation of an increased number of chondrocytes that resulted in an accumulation of cells and extracellular matrix in this zone. Our results clearly show that both phytase supplementation and inorganic $P$ additions significantly narrowed the hypertrophy zone because of an increase in available P (Figs. 1(a), 2(a); Table 4) in a fashion similar to that seen by Long et al. (1984). The narrowed hypertrophy zone observed for supplemental phytase suggested that microbial phytase could improve bone cell growth, maturation and mineralization by increasing the availability of phytate $P$.

The cartilaginous and proliferative zones tended to be narrower and the trabecular bone became thinner and weaker for the tibia of poults fed with low levels of dietary $\mathrm{nP}$ but high levels of phytate P; these findings also agree with the findings of Long et al. (1984). In addition, irregular proximal ends of tibias of poults fed on low dietary $P$ tended to show uneven surfaces, loss of demarcation between cartilaginous and proliferative zones and irregular development of cartilaginous and bone cells that were small and less numerous (Figs. 1(b) and 2(b)). The lengthened cartilage columns in the hypertrophy zone were very apparent in $\mathbf{P}$ deficiency, and resulted from poor differentiation and mineralization of cartilage and bone cells, as also observed by Lacey \& Huffer (1982) and Long et al. (1984). All of these signs of P deficiency were also found in a broiler study (Qian et al. 1994), but they were more obvious in the turkeys of the present study than in the earlier broiler study. This may be due to the greater sensitivity of poults to $P$ deficiency. These collective observations clearly indicate that $P$ deficiency influences the orderliness of the histological development of tibia, and the degree of conversion of cartilage to bone in the tibia. An increase in bone ash mineral content was observed in the present study and related to incremental increases of supplemental phytase and inorganic $\mathrm{P}$; this relationship supports this pathogenesis hypothesis. The severity of the bone lesions owing to poor mineralization by $\mathbf{P}$ deficiency was noted by others to be closely related to the degree of $\mathbf{P}$ deficiency (Long et al. 1984). Our results clearly show that phytase reduces the histological abnormalities of tibia associated with $P$ deficiency (Table 4). This is suspected to be due to the supplemental phytase increasing the availability of minerals, especially $P$. The extent of the improvements to these histological traits of tibia was directly related to the amount of phytase added to the diets, which was similar to the effect of increments of added P. 
Supplemental phytase and/or inorganic P significantly increased tibial shear stress and tended to increase shear force. This is in agreement with the results reported by Denbow et al. (1993). Tibial shear stress is a more sensitive property than shear force to use in making bone strength comparisons, because it considers differences in the size and shape of the bone (Patterson et al. 1986). Strong bones produced by supplemental phytase suggest that phytase could improve the bone calcification that results in stronger bone.

The tibias of poults fed on diets containing supplemental inorganic $\mathrm{P}$ and/or phytase were longer and wider than those of poults fed with low dietary $\mathrm{nP}$ levels and no supplemental phytase. This was attributed to the fact that added phytase promotes bone growth and development by enhancing the availabilities of dietary phytate $\mathbf{P}$ and other minerals (Denbow et al. 1993; Qian et al. 1994; Ravindran et al. 1995).

Improvements in the performance of turkey poults also resulted from the increases in the availability of phytate $P$ by phytase supplementation. Increased bioavailabilities of other nutrients, such as trace minerals and protein (amino acids), were also possible reasons for the improvements in performance (Beers \& Jongbloed, 1992; Mroz et al. 1994; Qian et al. 1994). The improvement in gain:feed caused by supplemental phytase suggested that phytase increased body-weight gain not only by enhancing feed intake but also by improving feed efficiency. Some previous reports using broilers have shown improved gain:feed ratios when phytase is added to the diet (Simons et al. 1990; Saylor et al. 1991).

\section{CONCLUSION}

The histological hallmark of $\mathbf{P}$ deficiency in turkey poults is widening of the hypertrophy zone which results from defective cartilage and bone differentiation. Microbial phytase supplementation improves bone histological, mechanical and chemical characteristics by promoting normal bone development and mineralization. This improvement results from improved mineral bioavailability for turkey poults when phytase is added to high-phytate diets with low levels of $\mathrm{nP}$. Improvements in bone traits caused by supplemental phytase were similar to those observed for added inorganic $P$.

Appreciation is expressed to the United Soybean Board and the John Lee Pratt Animal Nutrition Program for financial support, to Dr V. Ravindran and Dr D. M. Denbow for poults' care and performance data collection, and to Cindy Hixon for typing the manuscript. This material is based on work supported in part by the Cooperative State Research Service, USDA, under project no. 132702.

\section{REFERENCES}

Association of Official Analytical Chemists (1990). Official Methods of Analysis, 15th ed. Arlington, Virginia: AOAC.

Beers, S. B. M. \& Jongbloed, A. W. (1992). Effect of supplementary Aspergillus niger phytase in diets for piglets on their performance and apparent digestibility of phosphorus. Animal Production 55, 425-430.

Combs, N. R., Kornegay, E. T., Lindemann, M. D., Notter, D. R., Wilson, J. H. \& Mason, J. P. (1991). Calcium and phosphorus requirement of swine from weanling to market weight: II. Development of response curves for bone criteria and comparison of bending and shear bone testing. Journal of Animal Science 59, 682-698.

Consortium (1988). Guide For the Care and Use of Agricultural Animals in Agricultural Research and Teaching. Champaign, IL: Consortium For Developing a Guide For the Care and Use of Agricultural Animals in Agricultural Research and Teaching.

Denbow, D. M., Ravindran, V., Kornegay, E. T., Self, B. B. \& Hulet, R. M. (1993). Improved availability of phosphorus in soybean meal for broiler chicks by supplemental phytase. Poultry Science 72, Suppl. 1, 84 Abstr.

Edwards, H. M. \& Veltamann, J. R. (1988). The role of calcium and phosphorus in the etiology of tibial dyschondroplasia in young chicks. Journal of Nutrition 113, 1568-1575.

Engelen, A. J., van der Heeft, F. C., Randsdorp, P. H. G. \& Smit, L. C. (1994). Simple and rapid determination of phytase activity. Journal of the Association of Official Analytical Chemists International 77, 760-764. 
Lacey, D. L. \& Huffer, W. E. (1982). Studies on the pathogenesis of avian rickets. I. Changes in epiphyseal and metaphyseal vessels in hypocalcemic and hypophosphatemic rickets. American Journal of Pathology 109, 288-301

Long, P. H., Lee, S. R., Rowland, G. N. \& Britton, W. M. (1984). Experimental rickets in broilers: gross, microscopic, and radiographic lesions. I. Phosphorus deficiency and calcium excess. Avian Diseases 28, 460-474.

Mroz, Z., Jongbloed, A. W. \& Kemme, P. A. (1994). Apparent digestibility and retention of nutrients bound to phytate complexes as influenced by microbial phytase and feeding regimen in pigs. Journal of Animal Science 72, 126-132.

National Research Council (1994). Nutrient Requirements of Poultry, 9th ed. Washington, DC: National Academy of Sciences.

Patterson, P. H., Cook, M. E., Crenshaw, T. D. \& Sunde, M. L. (1986). Mechanical properties of the tibia tarsus of broilers and poults loaded with artificial weight and fed various dietary protein levels. Poultry Science $\mathbf{6 5}$, 1357-1364.

Qian, H., Veit, H. P., Kornegay, E. T., Ravindran, V. \& Denbow, D. M. (1994). Effects of supplemental phytase on histological and other characteristics and performances of broilers fed semi-purified diets. Journal of Animal Science 72, Suppl. 2, 8 Abstr.

Ravindran, V., Kornegay, E. T., Denbow, D. M., Yi, Z. \& Hulet, R. M. (1995). Response of turkey poults to tiered levels of Natuphos ${ }^{\circledR}$ phytase added to soybean meal-based semi-purified diets containing three levels of nonphytate phosphorus. Poultry Science 74, 1843-1854.

Reddy, N. R., Sathe, S. K. \& Salunkhe, T. (1982). Phytates in legumes and cereals. In Advances in Food Research, pp. 1-91 [C. O. Chichester, E. M. Mrak and G. F. Stewart, editors]. New York: Academic Press.

Saylor, W., Bartnikowski, W. \& Spencer, T. L. (1991). Improved performance of broiler chicks fed diets containing phytase. Poultry Science 70, 104 Abstr.

Simons, P. C. M., Versteegh, H. A. J., Jongbloed, A. W. \& Kemme, P. A. (1990). Improvement of phosphorus availability by microbial phytase in broilers and pigs. British Journal of Nutrition 64, 525-540.

Statistical Analysis Systems (1992). SAS/STAT User's Guide: Statistics, release 6.04. Cary, NC: SAS Institute Inc.

Sullivan, T. W. \& Douglas, J. H. (1990). Phosphorus bioassays - developments in five decades. In Proceedings of the Nutrition for the Nineties Conference, pp. 18-37. Bloomington, MN: Pitman-Moore.

Underwood, E. J. (1981). The Mineral Nutrition of Livestock, 2nd ed. Slough: Commonwealth Agricultural Bureaux.

Walker, A. R. P., Walker, B. F. \& Olatthaar, I. I. (1992). Fiber, phytic acid and mineral metabolism. Nutrition Reviews 50, 30-32.

Wise, A. (1983). Dietary factors determining the biological activities of phytate. Nutrition Abstracts and Reviews 53, 791-806.

Yoshida, M. (1986). Difference in availability of phosphorus in cereals by the chick. Japanese Poultry Science $\mathbf{2 3}$, $1-8$. 